\title{
Effect of abscisic acid on the mobilisation of galactomannan and embryo development of Sesbania virgata (Cav.) Pers. (Leguminosae - Faboideae) ${ }^{1}$
}

\author{
ADRIANA POTOMATI ${ }^{2}$ and MARCOS S. BUCKERIDGE ${ }^{2,3}$
}

(received: January 11, 2001; accepted: May 22, 2002)

\begin{abstract}
Effect of abscisic acid on the mobilisation of galactomannan and embryo development of Sesbania virgata (Cav.) Pers. (Leguminosae - Faboideae)). Galactomannans (GM) are storage cell wall polysaccharides present in endospermic seeds of legumes. They are thought to be storage polymers, since it has been observed for a few species (among them Sesbania virgata) that they are completely broken down after germination and their products are transferred to the growing embryo. We examined the effect of $10^{-4} \mathrm{M}$ abscisic acid (ABA) on the degradation of galactomannan in isolated endosperms and intact seeds of $S$. virgata. We found that after seed germination the initial embryo growth was retarded. Ultrastructural analysis showed that the embryo is completely surrounded by an endosperm which displays very thick galactomannan-containing cell walls. Although an inhibitory effect has been observed on the increase of fresh mass of the embryo, the effect of ABA on the dry mass was weaker and transitory (from 48 to $96 \mathrm{~h}$ ). Endosperm dry mass and galactomannan degradation were significantly inhibited and the activity of $\alpha$-galactosidase was strongly affected. The addition of ABA before and/or after the start of mobilisation in intact seeds or isolated endosperms, showed that whereas addition before mobilisation did not affect dry mass decrease in intact seeds, it was strongly affected in isolated endosperms. On the other hand, whereas it affected embryo fresh mass increase in intact seeds, but not in isolated embryos, no significant effect was observed on dry mass. These results suggest that $\mathrm{ABA}$ affects galactomannan degradation and by doing so, prevents water absorption by the embryo, rather than affect its dry mass. As ABA has been detected in the endosperm of seeds of S. virgata, it is proposed that it probably acts as a modulator of galactomannan mobilisation and consequently synchronises it with early growth of the embryo.
\end{abstract}

RESUMO - (Efeito do ácido abscísico sobre a mobilização de galactomanano e desenvolvimento do embrião de Sesbania virgata (Cav.) Pers. (Leguminosae - Faboideae)). As sementes de Sesbania virgata (Leguminosae - Faboideae) acumulam galactomanano no endosperma, o qual é degradado após a germinação e seus produtos de degradação são transferidos para o embrião em crescimento. Neste trabalho verificou-se que o ácido abscísico $\left(\mathrm{ABA} 10^{-4} \mathrm{M}\right)$ retarda a germinação de sementes de $S$. virgata e inibe o crescimento do embrião. Sobre as massas fresca e seca deste, o ABA teve efeito transitório sobre o segundo e efeito drástico sobre o primeiro, sugerindo que sua ação seja na absorção de água pelo embrião em crescimento. Um efeito parcial do ABA foi verificado sobre a degradação do galactomanano e sobre a atividade de uma das enzimas de degradação, a $\alpha$-galactosidase. O ABA atuou sobre a mobilização quando aplicado antes ou durante o período experimental e menos quando aplicado depois. O efeitos sobre a massa fresca do embrião foram similares aos observados para o endosperma, porém, não houve efeito sobre a massa seca do embrião. Quando endosperma e embriões isolados foram tratados de forma similar, observou-se efeito do ABA sobre a mobilização em todos os casos, mas sobre a massa fresca do embrião, este só foi verificado quando o $\mathrm{ABA}$ foi mantido durante todo o período experimental. Como houve uma grande diferença em massa fresca do embrião quando o endosperma foi retirado, concluiu-se que o galactomanano funciona mais como uma reserva de água do que de carbono para o embrião e que a ação do ABA parece ser principalmente na modulação da degradação do galactomanano e o processamento de seus produtos pelo embrião.

Key words - abscisic acid, galactomannan, seed, Leguminosae, storage mobilisation

\section{Introduction}

The seeds of lettuce, tomato and many legumes are known to accumulate galactomannan or galactoglucomannan in their endospermic cell walls (Halmer \& Bewley 1979, Buckeridge et al. 2000a,b).

\footnotetext{
1. Part of the MSc thesis by A.P. presented to Universidade Estadual de Campinas, Departamento de Biologia Celular e Estrutural.

2. Instituto de Botânica, Seção de Fisiologia e Bioquímica de Plantas, Caixa Postal 4005, 01061-970 São Paulo, SP, Brazil.

3. Corresponding author: msbuck@usp.br
}

These polymers are broken down after germination, producing free galactose and mannose which serve as a source of carbon and energy for the growing seedling (Reid 1971, McCleary \& Matheson 1974, Buckeridge \& Dietrich 1996). Galactomannan has therefore been considered as a storage polysaccharide (Reid 1985). However, galactomannan has also been demonstrated to perform other functions, such as weakening of the endosperm of tomato seeds to facilitate radicle protrusion (Groot \& Karsen 1987) and to control water imbibition in seeds of fenugreek (Trigonella foenum-graecum L.) (Reid \& Bewley 1979). 
Groot \& Karsen (1987) demonstrated that gibberellin regulates seed germination through the induction of endosperm weakening in tomato and Spyropoulos \& Reid (1985) suggested that the endosperm of legumes might be under control of auxin and gibberellin. When isolated and incubated in relatively small volumes of water, the endosperms of lettuce (Dulson et al. 1988) and fenugreek (Spyropoulus \& Reid 1988) were not capable of completing galactomannan degradation. However, they did so when incubated in larger volumes. On this basis, these authors proposed the existence of a water soluble inhibitor(s) which is somehow inactivated (or degradated) during germination and consequently liberates storage cell wall mobilisation.

Galactomannan mobilisation is inhibited by abscisic acid (ABA) in seeds of lettuce (Halmer \& Bewley 1979), tomato (Groot \& Karsen 1992) and fenugreek (Kontos \& Spyropoulos 1995). In these studies, exogenously applied ABA has been demonstrated to interfere with the activity of galactomannan-hydrolysing enzymes. Dulson et al. (1988) detected the presence of endogenous ABA in seeds of lettuce and proposed that it plays a role in the regulation of endo- $\beta$-mannanase production in isolated lettuce endosperms.

Galactomannan mobilisation in endosperms of Sesbania virgata (Cav.) Pers. was followed during and after germination, the enzymes $\alpha$-galactosidase, endo- $\beta$-mannanase and exo-mannanase being the principal enzymes involved (Buckeridge \& Dietrich 1996). S. virgata (published by our group under the synonym of Sesbania marginata Benth.) is a legume shrub that occurs mainly in the gallery forests in tropical regions and is associated with early stages of ecological succession. Thus, understanding how storage mobilisation is controlled at early stages of plantlet establishment is of great value to comprehend how plants at different stages of succession are able to adapt to their natural environmental conditions. Taking these facts into consideration, in the present work we studied the effect of exogenously applied ABA on isolated endosperm and intact seeds of Sesbania virgata, with the objective of understanding physiological mechanisms correlated with its strategy of adaptation of plantlets of $S$. virgata to its natural environment.

\section{Material and methods}

Material - Seeds of Sesbania virgata (Cav.) Pers. were obtained from plants cultivated under natural conditions in the gardens of the Instituto de Botânica in São Paulo, Brazil. Scanning electron microscopy (SEM) - For the examination of ultrastructural characteristics of seeds of Sesbania virgata, pieces of quiescent seeds were mounted on stubs and subsequently coated with gold (Baltec SCD 050 coater), examined and photographed in a Philips Scanning Electron Microscope XL20 at an accelerating voltage of $10 \mathrm{kV}$.

Light microscopy - For light microscopy observations, seeds of Sesbania virgata were soaked in distilled water for $24 \mathrm{~h}$ at room temperature and transversally cut into $10 \mu \mathrm{m}$-thick slices using a cryostat microtome. Sections were placed on glass slides and covered with $0.1 \%$ methylene blue and incubated for $1 \mathrm{~min}$ at $60^{\circ} \mathrm{C}$. The excess of methylene blue was taken out by blotting the slide on Whatman number 3 paper. The sections were observed and photographed directly using a camera attached-microscope (Carl Zeiss-Jena).

Seed germination and sampling - Seeds of Sesbania virgata were scarified, one by one, by abrading the seed coat in the region below the lens with sandpaper. They were sterilised with sodium hypochlorite ( $0.75 \%$ active chlorine) for $15 \mathrm{~min}$. and washed with sterile distilled water. They were then placed in $9 \mathrm{~cm}$ diameter Petri dishes (four plates containing 30 seeds/plate) under continuous light (mixture of fluorescent and incandescent bulbs with photon flux density of approximately $50 \mu \mathrm{mol} \cdot \mathrm{m}^{-2} \cdot \mathrm{s}^{-1}$ ).

Seeds were incubated at $30{ }^{\circ} \mathrm{C}$ in $16 \mathrm{ml}$ of water or abscisic acid $\left(10^{-4} \mathrm{M}\right.$ ABA, Sigma Chem. Co.) for $17 \mathrm{~h}$, when complete imbibition was observed. Five samples of 16 seeds were harvested daily and immediately dissected in order to separate the endosperm plus seed coat from the embryo (cotyledons plus embryonic axis). Another five samples were maintained intact during the entire experimental period $(144 \mathrm{~h})$ and then dissected. After recording the fresh mass of separate seed parts of each sample, they were dried at $80^{\circ} \mathrm{C}$. When constant weight was attained (after approximately $48 \mathrm{~h}$ ) the dry mass was recorded. As it has been calculated that $50 \%$ of dry mass of the endosperm plus seed coat correspond to galactomannan (Buckeridge \& Dietrich 1996), the loss of half of the dry mass of endosperm was considered as $100 \%$ of degradation.

Using the general procedure described above, several parameters were evaluated every $24 \mathrm{~h}$ in the following way: (W) seeds maintained in water from 0 to $144 \mathrm{~h}$; (W/A) seeds maintained in water from 0 to $17 \mathrm{~h}$ and transferred to $10^{-4} \mathrm{M}$ ABA until $144 \mathrm{~h}$; (A/W) seeds maintained $10^{-4} \mathrm{M}$ ABA from 0 to $17 \mathrm{~h}$ and transferred to water until $144 \mathrm{~h}$; (A) seeds maintained in $10^{-4} \mathrm{M}$ ABA from 0 to $144 \mathrm{~h}$.

Galactomannan extraction - Galactomannan was extracted from powdered endosperm plus seed coat with hot water $\left(80^{\circ} \mathrm{C}, 0.1 \mathrm{~g} \cdot \mathrm{ml}^{-1}\right)$ for $8 \mathrm{~h}$. After filtration through cheesecloth, centrifugation was performed $\left(10,000 \mathrm{~g}, 30 \mathrm{~min} ., 5^{\circ} \mathrm{C}\right)$ followed by precipitation with 3 volumes of ethanol. The precipitate was left overnight at $5^{\circ} \mathrm{C}$, collected by centrifugation, dried and weighed. This crude polysaccharide was considered as the galactomannan which was quantified gravimetrically 
(modified from Anderson 1949).

Extraction and detection of $\alpha$-galactosidase - The time course of $\alpha$-galactosidase activity in endosperm of Sesbania virgata was determined by placing seeds to germinate under the same conditions as above, separating daily the endosperm plus seed coat from the embryo up to the $6^{\text {th }}$ day followed by extraction and assay of crude preparations for $\alpha$-galactosidase as described below.

The samples (three replicates of endosperms corresponding to 30 seeds) were crushed with $10 \mathrm{ml}$ of $20 \mathrm{mM}$ sodium acetate buffer $\mathrm{pH} 5.0$ at $5^{\circ} \mathrm{C}$ and centrifuged $\left(10,000 \mathrm{~g}, 30 \mathrm{~min} ., 5^{\circ} \mathrm{C}\right)$. Aliquots of the supernatant were assayed for $\alpha$-galactosidase activity using a $50 \mathrm{mM}$ solution of $\rho$-nitrophenyl- $\alpha$-D-galactopyranoside (Sigma Chem. Co., St Louis, USA) as substrate. The reaction was stopped by addition of $0.1 \mathrm{~N} \mathrm{Na}_{2} \mathrm{CO}_{3}$ and the absorbance determined at 405 nm (Reid \& Meier 1973).

\section{Results and Discussion}

Effect of ABA on seed germination - Abscisic acid at $10^{-4} \mathrm{M}$ strongly retarded germination of seeds of Sesbania virgata. After $24 \mathrm{~h}, \mathrm{ABA}$ apparently inhibited germination completely, but these seeds reached $100 \%$ germination after $96 \mathrm{~h}$ (figure 1A). This behaviour characterised a retardation rather than complete inhibition. This effect is probably a reflection of the effect of ABA on embryo growth rather than on germination itself. On the other hand, when seedling growth was evaluated by measurement of radicle length, a significant inhibition was observed (figure 1B) even after $96 \mathrm{~h}$. As this is a more accurate form of evaluation of the effect of ABA on early growth than radicle protrusion alone, it can be concluded that $\mathrm{ABA}$ has a permanent (rather than retardation only) effect on seedling growth.

Morphology of seeds - As a typical legume seed from the subfamily Faboideae, Sesbania virgata possesses an endosperm, which completely surrounds the embryo (figure 2A, see also Buckeridge \& Dietrich 1996). Under larger magnification (figure $2 \mathrm{~B}$ ), it can be seen that the seed coat presents a layer of osteosclereids as well as a parenchyma layer. Furthermore, between seed coat and endosperm, an aleurone layer is present (figure 2D), which is assumed, by comparison with Reid (1971), to produce the enzymes responsible for galactomannan degradation. Large amounts of galactomannan were shown to be present in endosperm cell walls by Buckeridge \& Dietrich (1996) and this can also be noted in figures $2 \mathrm{C}$ and $2 \mathrm{D}$.

Reid and Bewley (1979) observed that the endosperm of seeds of Trigonella foenum-graecum
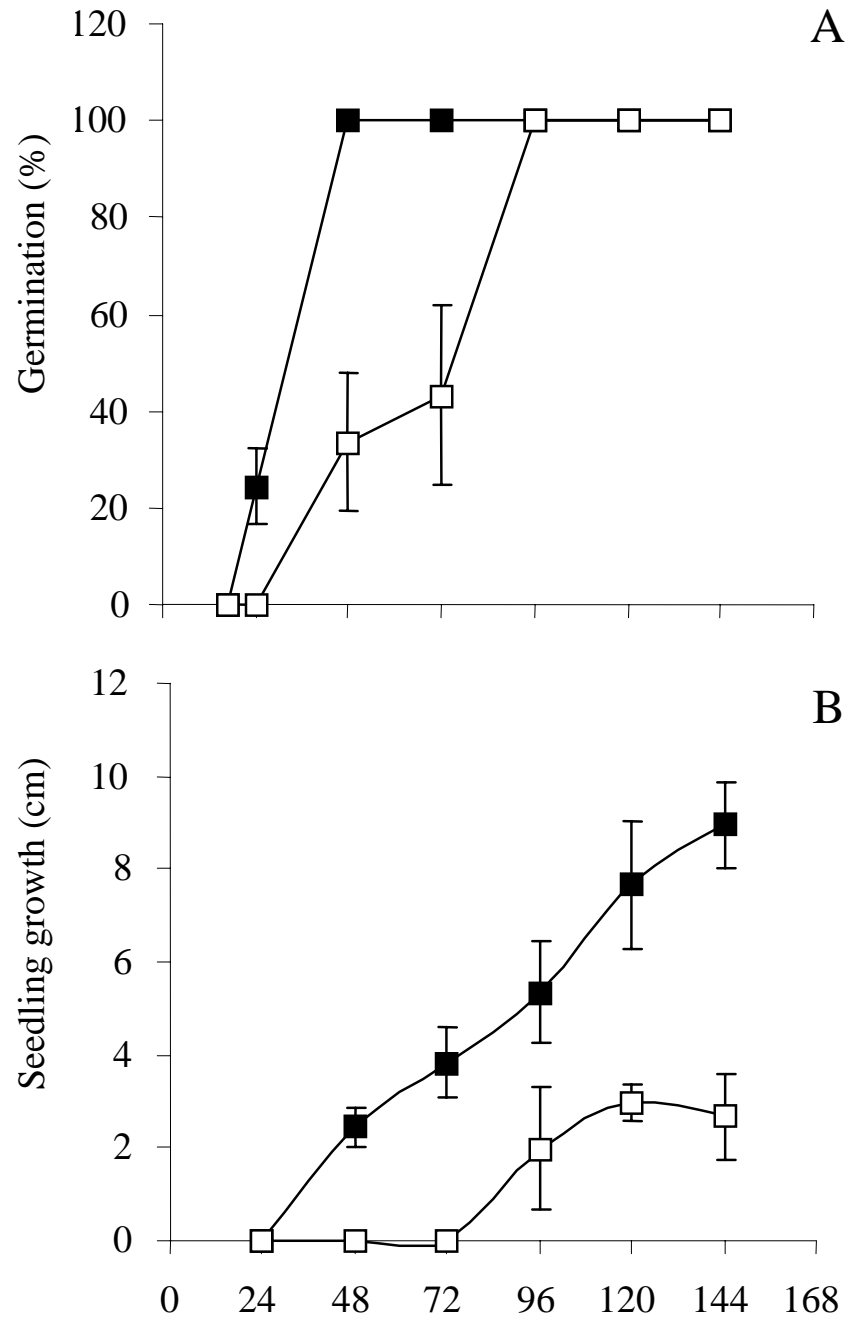

Time (h)

Figure 1. Effect of exogenously applied ABA $\left(10^{-4} \mathrm{M}\right)$ on germination of seeds of Sesbania virgata (A) and on plantlet growth (B) during six days after imbibition ( $\square$ water, $\square$ ABA). The data represent the mean of four replicates \pm SD.

imbibes most of the water (ca. 60\%) taken by the seed. On the basis of some hydrodynamic properties of galactomannan such as high viscosity and also the fact that it binds water strongly, those authors proposed that the endosperm would play a role as a "water buffer" following germination. Thus, as water enters the endosperm and it becomes completely imbibed, any change in environmental conditions which is capable of decreasing water availability, would induce water loss firstly from the endosperm and only later on from the embryo.

Besides protection against water loss, it is possible that the presence of galactomannan in the endosperm 


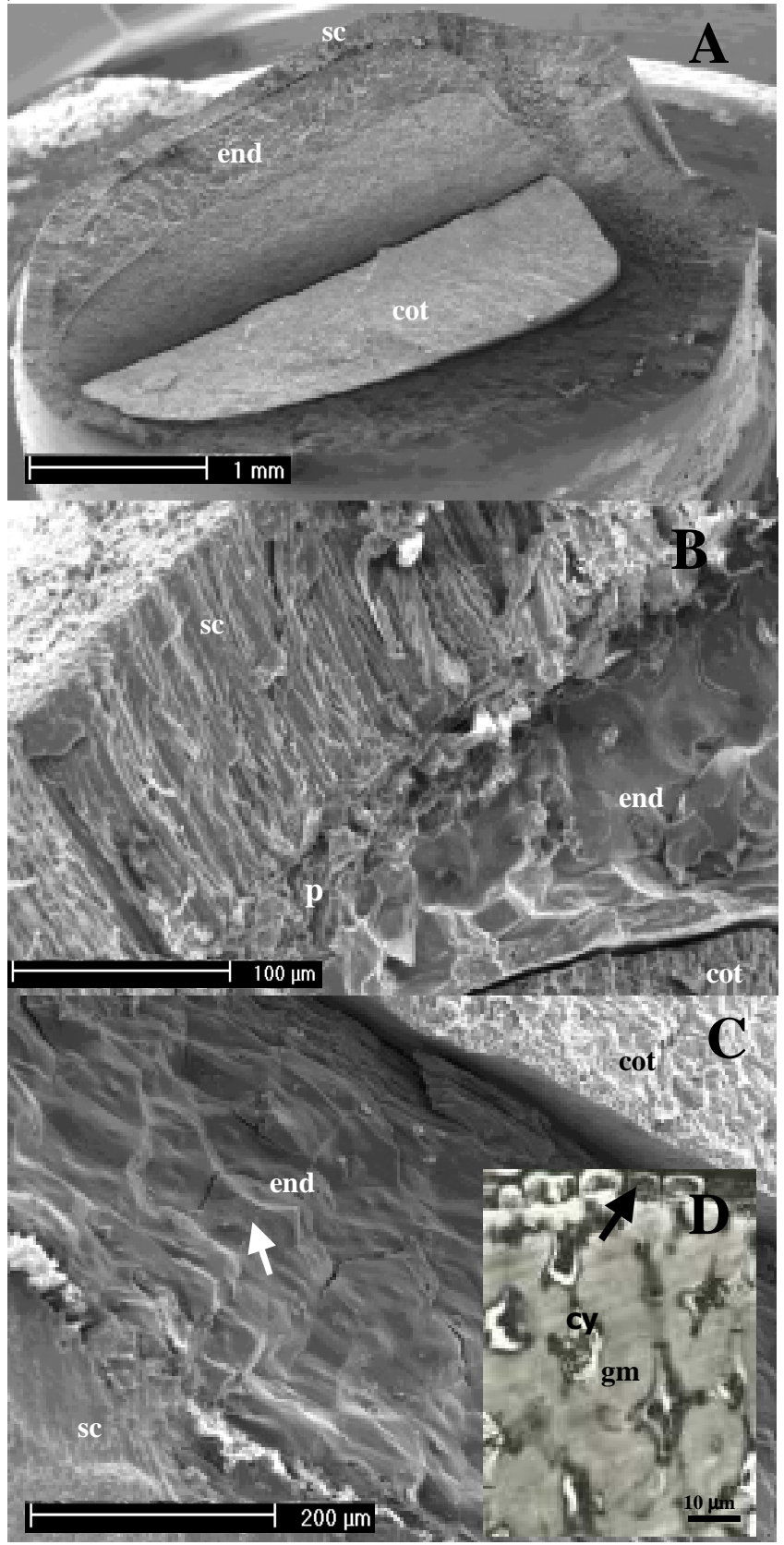

Figure 2. Ultrastructural analysis of the seed of Sesbania virgata. A. General view of transversally broken seed showing the seed coat (sc), endosperm (end) and cotyledons (cot); B. and $\mathrm{C}$. Higher magnifications showing details of the connections between seed coat (sc), parenchyma layer (p), endosperm (end) containing thick cell walls (white arrow in C) and cotyledons (cot); D. Light microscopy showing the aleurone layer (black arrow), cytoplasm (cy) and endospermic cell walls thickened with galactomannan (gm).

might play a role in synchronising metabolic events in course in the endosperm and embryo following germination. Taking this into consideration, along with the facts that i) ABA is present in the endosperm of seeds of Sesbania virgata (H. Mercier \& M.S. Buckeridge, unpublished data) and ii) that exogenously applied ABA has an effect on germination and growth of the seed and seedling of this species respectively, we examined the effect of the hormone on different seed parts. These experiments had the purpose to evaluate the physiological importance of $\mathrm{ABA}$ for synchronisation of storage cell wall mobilisation and seedling growth in $S$. virgata.

Effect of ABA on the embryo - The figure 3 shows changes in dry and fresh mass of seedling of Sesbania virgata up to six days in $10^{-4} \mathrm{M}$ ABA or water. The fresh mass was strongly affected throughout the
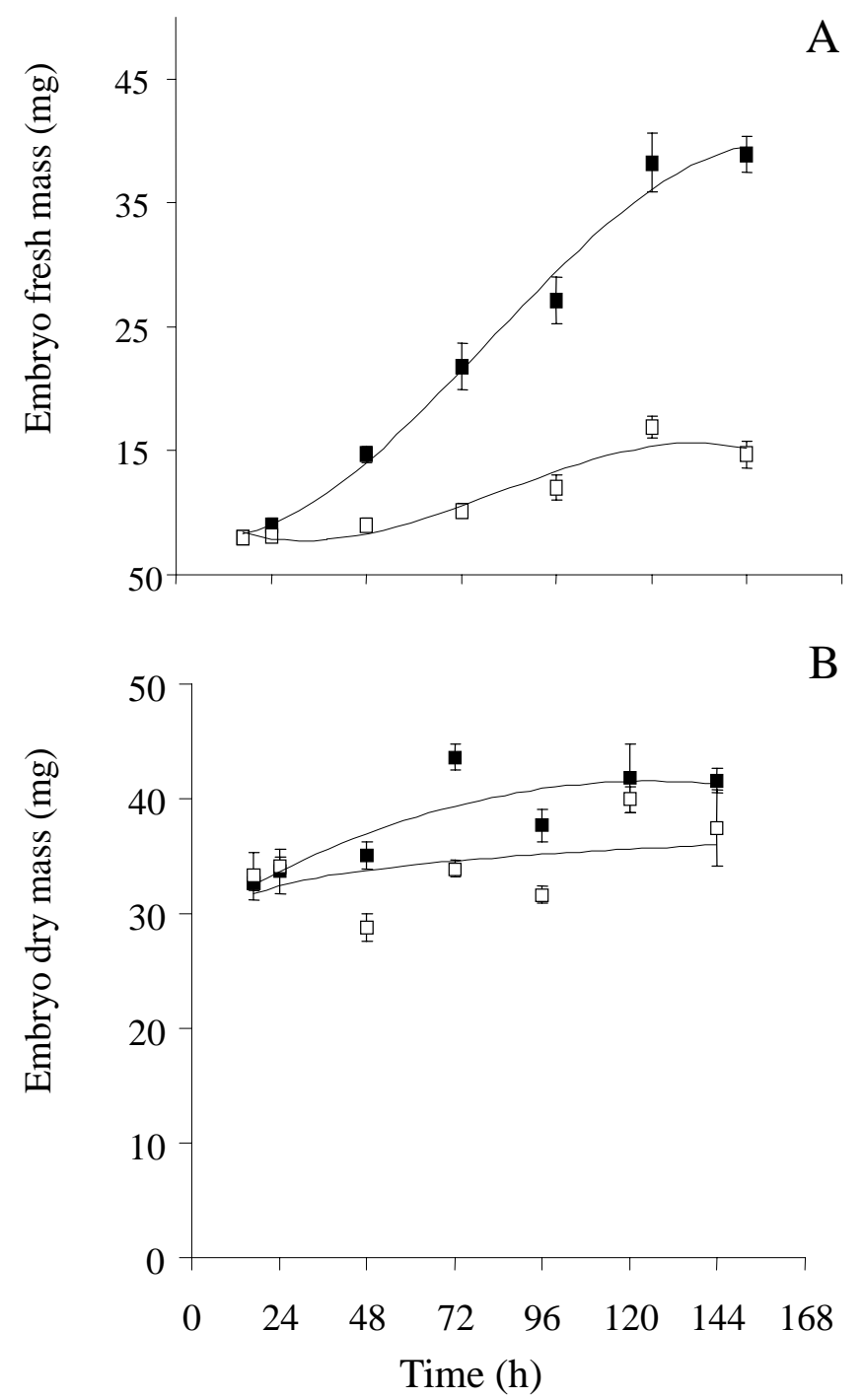

Figure 3. Effect of exogenously applied $\mathrm{ABA}\left(10^{-4} \mathrm{M}\right)$ on the fresh mass (A) and dry mass (B) of the embryo during germination of seeds of Sesbania virgata. Intact seeds were put to germinate in water or $\mathrm{ABA}$ and measurements were made every $24 \mathrm{~h}$ for six days ( $\mathbf{w}$ water, $\square$ ABA). The data represent the mean of four replicates $\pm \mathrm{SD}$. 
experimental period (figure 3A) whereas the dry mass was relatively less affected, showing some effect only between 50 and $100 \mathrm{~h}$ (figure 3B). As the effect of ABA on the fresh mass is stronger than on the dry mass, it is possible that the water uptake by the embryo was affected by ABA with little effect on dry mass. As this experiment was performed with intact seeds and under this condition the embryo is completely surrounded by the endosperm, the effect of ABA could be either direct or indirect. In other words, the effect of the hormone on embryo growth might be a consequence of a stronger effect on the endosperm.

Effect of ABA on the endosperm - The figure 4A shows that the decrease in endosperm dry mass, which is in great part affected by galactomannan degradation (Buckeridge \& Reid 1996), was significantly inhibited by $10^{-4} \mathrm{M}$ ABA after six days ( $144 \mathrm{~h}$ ) of germination. Indeed, galactomannan degradation was partially inhibited following germination (figure 4B) and this inhibition was corroborated by reduction of the early increase in $\alpha$-galactosidase activity in the endosperm (figure 4C).

Buckeridge \& Dietrich (1996) showed that galactomannan degradation in seeds of Sesbania virgata starts only after radicle protrusion. Also, Spyropoulos \& Reid (1985) showed that isolated endosperms of seeds of Trigonella foenum-graecum are not capable to perform galactomannan degradation, unless a water soluble inhibitor is leaked out from the endosperm. It is reasonably well accepted that in seeds of T. foenum-graecum, the galactomannan hydrolases are produced in the aleurone layer and translocated to the endosperm, where galactomannan degradation takes place. Furthermore, the morphology of the seeds of $S$. virgata (figure 2) is closer to the one of T. foenum-graecum and Cyamopsis tetragonolobus (L.) Taub. than, for example, to the seeds of Ceratonia siliqua L., which does not possess an aleurone layer, the enzymes being produced into the cytoplasm of endosperm cells (Buckeridge et al. 2000b).

Taking these information into account, we performed two combined experiments designed to check two different points: 1) when does ABA exert its effect? Before or after radicle protrusion? 2) where is ABA primary effect located? Endosperm or embryo? The figures 5 and 6 show the results of these experiments, in which dissected (into endosperm and embryo) or intact seeds of Sesbania virgata were incubated in water or $10^{-4} \mathrm{M}$ ABA up to six days.

The figure $5 \mathrm{~A}$ shows changes in dry mass of endosperms of intact seeds incubated under different
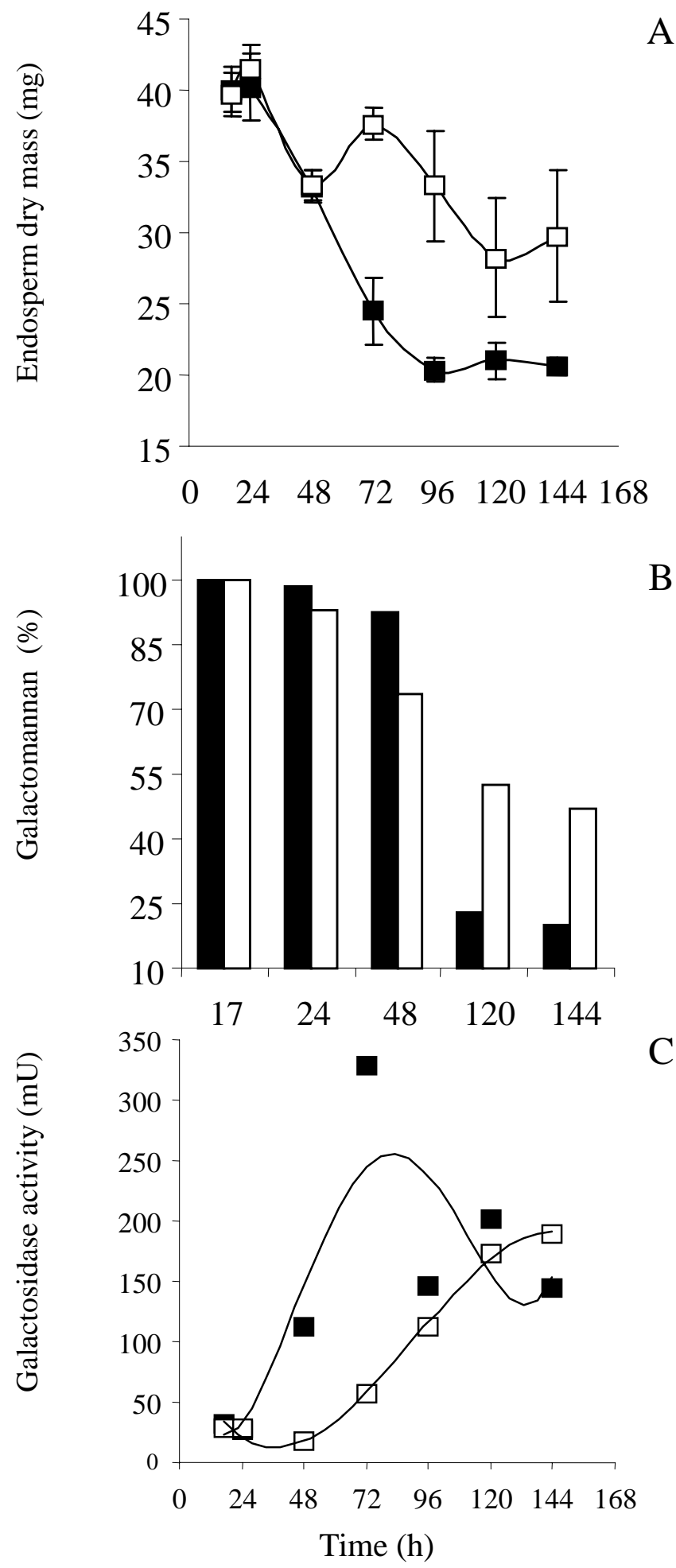

Figure 4. Effect of exogenously applied ABA $\left(10^{-4} \mathrm{M}\right)$ on galactomannan degradation following germination (up to 6 days) of seeds of Sesbania virgata. Dry mass of the endosperm following degradation (A); yield of galactomannan (B); activity of $\alpha$-galactosidase (C) ( $\mathbf{\square}$ water, $\square$ ABA). In (A), the data represent the mean of four replicates $\pm \mathrm{SD}$. The data in (B) and (C) represent means of three samples, which were pooled before determination. 

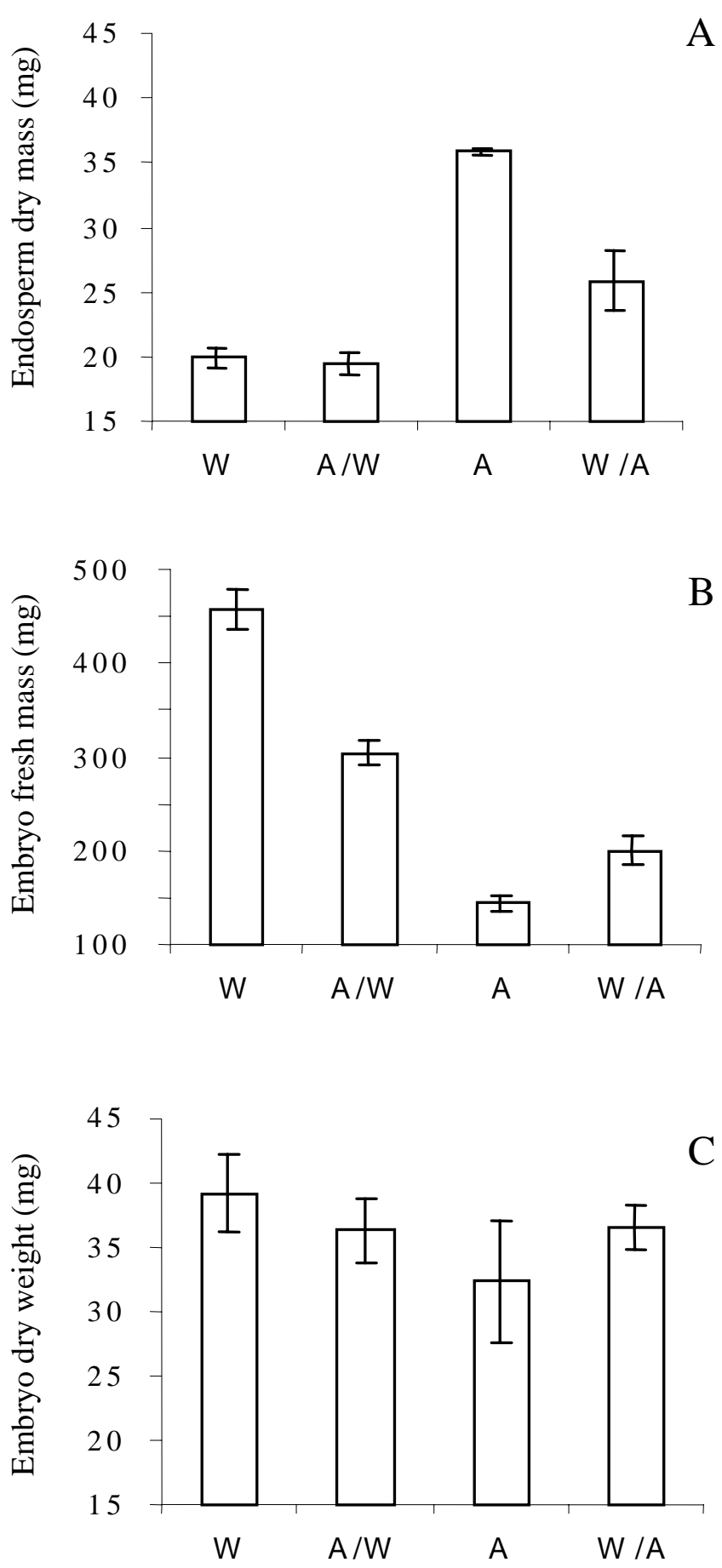

Treatments

Figure 5. Effect of ABA $\left(10^{-4} \mathrm{M}\right)$ on the dry mass of the endosperm (A) and the fresh (B) and dry (C) masses of the embryo after $144 \mathrm{~h}$ of imbibition. Seeds of Sesbania virgata were maintained in the different treatments: $\mathrm{W}=$ in water for $144 \mathrm{~h}, \mathrm{~A} / \mathrm{W}=$ in $\mathrm{ABA}$ and after $17 \mathrm{~h}$ they were maintained in water $\mathrm{A}=$ in $\mathrm{ABA}$ for $144 \mathrm{~h}$, and $\mathrm{W} / \mathrm{A}=$ in water and after $17 \mathrm{~h}$ maintained in ABA. Standard deviation were obtained with five replicates. conditions. When incubated in water for six days (W), galactomannan degradation is completed (dry mass decreases to $20 \mathrm{mg}$ per seed). If $10^{-4} \mathrm{M} \mathrm{ABA}$ is added up to $17 \mathrm{~h}$ (before radicle protrusion) and kept in water up to six days $(\mathrm{A} / \mathrm{W})$, galactomannan degradation occurs as under incubation in water. When in ABA for the whole period (A), strong inhibition of degradation was observed. However, a partial effect was observed when ABA was added after radicle protrusion (W/A). These results suggest that $\mathrm{ABA}$ has its effect after radicle protrusion, i.e. possibly after hydrolytic enzymes are already synthesised.

These results can be compared to the ones presented in figure 6A, where isolated endosperms/ embryos were subjected to the same treatments. Differently from what happened with intact seeds, in isolated endosperms $\mathrm{ABA}$ had a significant effect when added before $17 \mathrm{~h}(\mathrm{~A} / \mathrm{W})$ and equally when incubated during the whole experimental period (A) or after $17 \mathrm{~h}$ only (W/A). It is clear from this comparison that endosperms of seeds of Sesbania virgata present the same behaviour as Trigonella foenum-graecum in the sense that isolated endosperms showed inhibition of galactomannan degradation.

The effects of ABA on the embryo under the same conditions described above confirmed the observation that it has little or no effect on the dry mass (compare figures $5 \mathrm{C}$ and $6 \mathrm{C}$ ), but had a stronger effect on the fresh mass (compare figures 5B and 6B). With isolated embryos, ABA had a significant effect only when present during all the experimental period, whereas a much stronger effect was observed in intact seeds, especially when $\mathrm{ABA}$ was present during six days (A in figure $5 \mathrm{~B}$ ).

The crossed analysis of the two experiments lead to the following suggestions: 1) there might be a cause-effect relationship between the effect of ABA on the endosperm and on the embryo, since as greater the effect of ABA on the former, the greater its the effect on the second; 2 ) the effect on the embryo seems to reflect mainly in water uptake, whereas in the endosperm both galactomannan and $\alpha$-galactosidase activity were affected.

The role of ABA on galactomannan mobilisation - As galactomannan has been suggested as an important substance in the control of water relations of legume endosperm (Reid \& Bewley 1979, Buckeridge \& Dietrich 1996), it is reasonable to assume that the uptake of water by the embryo might have been affected via inhibition of galactomannan degradation in the endosperm. This hypothesis was tested by determining 

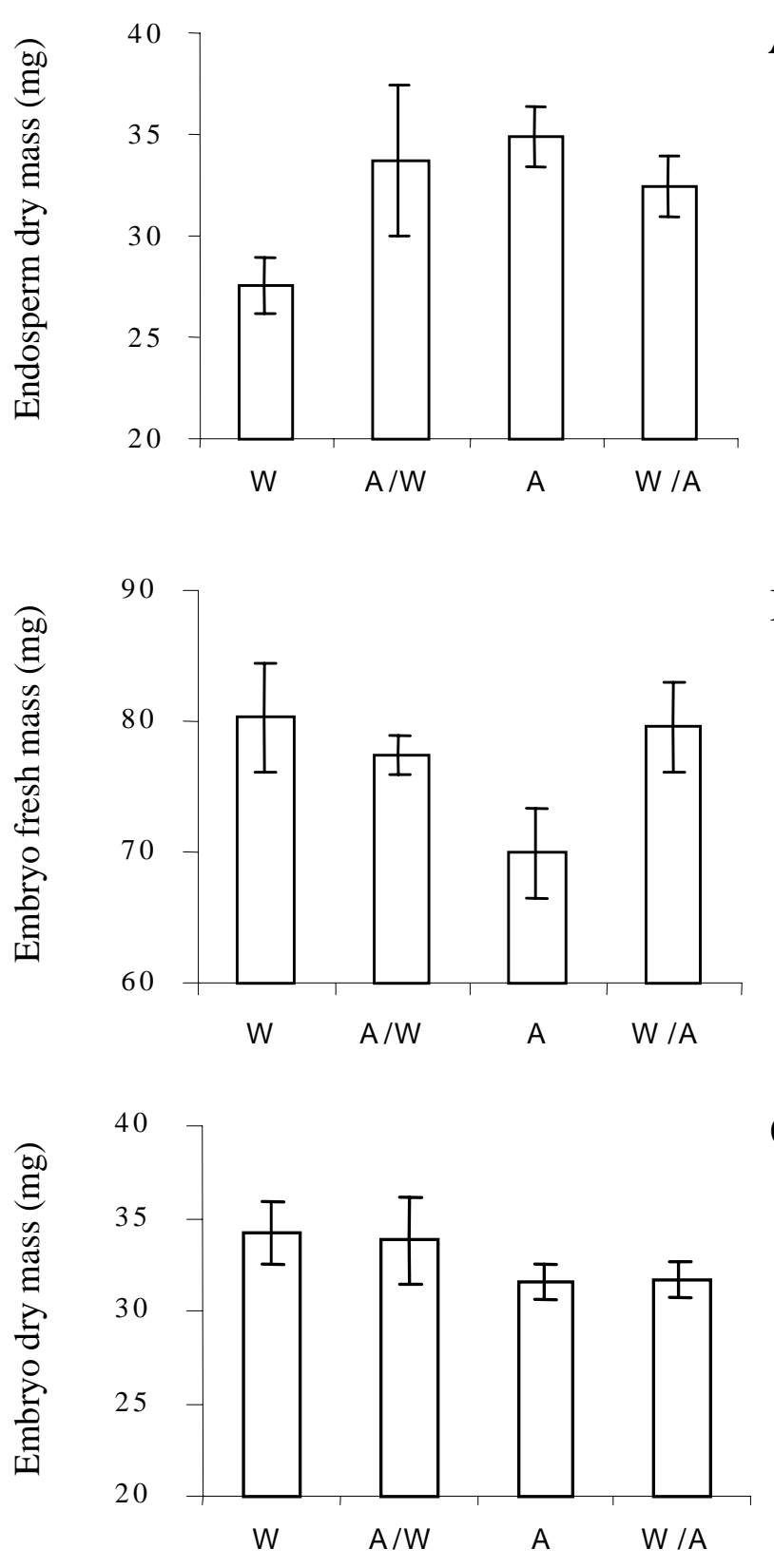

Treatments

Figure 6. Effect of ABA $\left(10^{-4} \mathrm{M}\right)$ on the dry mass of the isolated endosperm (A), fresh (B) and dry (C) mass of the isolated embryo after 144h of imbibition. Seeds of Sesbania virgata were placed to germinate under different treatments. After $17 \mathrm{~h}$, they were dissected and isolated embryos and endosperms were maintained in water imbibition for six days. Treatments were: $\mathrm{W}=$ seeds placed in water, dissected after $17 \mathrm{~h}$ and isolated embryos and endosperms maintained in water up to $144 \mathrm{~h}, \mathrm{~A}=$ maintained in $\mathrm{ABA}$ for $144 \mathrm{~h}, \mathrm{~W} / \mathrm{A}=$ seeds placed in water and after dissection they were maintained in $\mathrm{ABA}$ and $\mathrm{A} / \mathrm{W}=$ seeds placed in $\mathrm{ABA}$ and after dissection they were maintained in water. Standard deviation were obtained with five replicates.
A galactomannan yield and $\alpha$-galactosidase activity following germination with and without $\mathrm{ABA}$.

The presence of ABA in isolated endosperms of Sesbania virgata $\left(646.3 \pm 39.9\right.$ pmoles $\mathrm{g}^{-1}$ of fresh mass $)$, detected by immunoassay (H. Mercier \& M.S. Buckeridge, unpublished data), strongly suggests that this hormone is involved in the control of reserve mobilisation and indirectly controls seedling growth. It is likely that in seeds of $S$. virgata, ABA is the analogous to the inhibitor that has been detected in seeds of Trigonella foenum-graecum by Zambou et al. (1993). Thus, it is possible that, under natural conditions, the concentration of $\mathrm{ABA}$ decreases throughout germination, either by sink of the developing cotyledons, biochemical degradation or conjugation, in order to permit galactomannan mobilisation and consequently the release of the water retained during imbibition, to the growing embryo.

Acknowledgements - Authors wish to acknowledge the support by Biota-Fapesp(98/05124-8). A.P. acknowledges a fellowship from Capes and M.S.B. from CNPq.

\section{References}

ANDERSON, E. 1949. Endosperm mucilages of legumes: occurrence and composition. Industrial Engineer Chemistry 41:2887-2890.

BUCKERIDGE, M.S. \& DIETRICH, S.M.C. 1996. Mobilisation of the raffinose family oligosacharides and galactomannan in germinating seeds of Sesbania marginata Benth. (Leguminosae-Faboideae). Plant Science 117:33-43.

BUCKERIDGE, M.S., SANTOS, H.P. \& TINÉ, M.A.S. 2000a. Mobilisation of storage cell wall polysaccharides in seeds. Plant Physiology and Biochemistry 38:141-156.

BUCKERIDGE, M.S., DIETRICH, S.M.C. \& LIMA, D.U. 2000b. Galactomannans as the reserve carbohydrate in legume seeds. In Carbohydrate reserves in plants: Synthesis and regulation. (A.K. Gupta \& N. Kaur, eds.). Elsevier Science, Amsterdam, p.283-316.

DULSON, J., BEWLEY, J.D. \& JOHNSON, R.H. 1988. Abscisic acid is an endogenous inhibitor in the regulation of mannanase production by isolated lettuce endosperms. Plant Physiology 87:660-665.

GROOT, S.P.C. \& KARSEN, C.M. 1987. Gibberellins regulate seed germination in tomato by endosperm weakening. A study with giberellin-deficient mutants. Planta 171:525-531.

GROOT, S.P.C. \& KARSEN, C.M. 1992. Dormancy and germination of abscisic acid-deficient tomato seeds. Studies with the sitiens mutant. Plant Physiology 99:952-958. 
HALMER, P. \& BEWLEY, J.D. 1979. Mannanase production by the lettuce endosperm. Control by the embryo. Planta 144:330-340.

KONTOS, F. \& SPYROPOULOS, C.G. 1995. Production and secretion of $\alpha$-galactosidase and endo- $\beta$-mannanase activity by carob (Ceratonia siliqua L.) in the endosperm protoplasts. Journal of Experimental Botany 46:577-583.

McCLEARY, B.V. \& MATHESON, N.K. 1974. $\alpha$-Dgalactosidase activity and galactomannan and galactosylsucrose oligosaccharide depletion in germinating legume seeds. Phytochemistry 13:1747-1757.

REID, J.S.G. 1971. Reserve carbohydrate metabolism in germinating seeds of Trigonella foenum-graecum $\mathrm{L}$. Planta 100:131-142.

REID, J.S.G. 1985. Cell wall storage carbohydrates in seeds. Biochemistry of the seed "gums" and "hemicelluloses". Advances in Botanical Research 11:125-155.

REID, J.S.G. \& BEWLEY, J.D. 1979. A dual role for the endosperm and its galactomannan reserves in the germinative physiology of fenugreek (Trigonella foenum-graecum L.) an endospermic legume seed. Planta 147:145-150.
REID, J.S.G. \& MEIER, H. 1973. Enzyme activities and galactomannan mobilisation in germinating seeds of fenugreek (Trigonella foenum-graecum L. Leguminosae). Secretion of $\alpha$-galactosidases and $\beta$-mannosidase by the aleurone layer. Planta 112:301-308.

SPYROPOULOS, C.G. \& REID, J.S.G. 1985. Regulation of $\alpha$-galactosidase activity and the hydrolases of galactomannan in the endosperm of the fenugreek (Trigonella foenum-graecum) seed. Planta 166:271-275.

SPYROPOULOS, C.G. \& REID, J.S.G., 1988. Water stress and galactomannan breakdown in germinated fenugreek seeds. Stress affects the production and the activities in vivo of galactomannan hydrolysing enzymes. Planta 179:403-408.

ZAMBOU, K., SPYROPOULOS, C.G., CHINOU, I. \& KONTOS, F. 1993. Saponin-like substances inhibit $\alpha$-galactosidase production in the endosperm galactomannan degradation. Planta 189:207-212. 